\title{
FORESTRY EDUCATION/ÉDUCATION FORESTIÈRE
}

\author{
DEGREE PROGRAMS/PROGRAMME DE BACCALAURÉAT
}

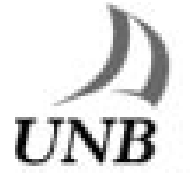

University of New Brunswick, Faculty of Forestry \& Environmental Managment, Fredericton, NB. Degree programs in Forestry (BScF) and Forest Engineering (BScFE) after grade XII or Quebec High School Leaving Examinations. The BsScF program includes a blend of biophysical, social, and management sciences; electives can lead to minors in Computer Applications, Economics, Business, Fredericton Wildlife (expandable to give Wildlife Biologist certification by the Wildlife Society), Parks and Wilderness, Environmental Studies, Wood Products or Forest Science. BScFE graduates are qualified to deal with engineering, implementation, and production aspects of management plans that are ecologically sound an economically feasible. Both programs include a provision for a Co-op term. Graduate programs leading to MScF of MF degrees are available in forest soils, hydrology and meteorology, ecology, management, economics, pathology, entomology, information systems, conservation, wildlife management, tree physiology, and wood science. MScFE and MFE programs are available in environmental studies, operations management, harvesting, wood supply, site preparation and stand establishment, geotechnical engineering, roads and transportation, industrial engineering, machine design wood products and wood engineering. PhD programs are available in the same fields. Enquiries should be directed to the Assistant Dean, P.O. Box 44555, E3B 6C2, or phone (506) 453-4501, E-mail: daug@unb.ca.

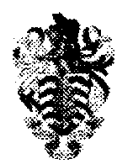

University of Toronto, Faculty of Forestry offers Ph.D. and M.Sc.F. research programs, focused primarily on forest conservation. Most fields of forestry are represented in graduate thesis research, particularly forest ecology, wildlife conservation, silviculture, forest soils and tree nutrition, soil erosion and land reclamation, fire management systems, forest entomology, tree physiology, community forestry, forest economics, wood science, fibre science, wood and composite product development, forest certification, urban forestry and international trade in forest products. The Faculty also offers a 16-month Master of Forest Conservation (M.F.C.) program, focused strongly on global forest conservation with a 3 month practical internship and an international field course; a collaborative Master of Wood Engineering (M.Sc.) program with the Faculty of Applied Science and Engineering, with industrial internships; and the Master of International Trade in Forest Products (MITFP) in collaboration with the Faculty of Law, the Rotman Schoo of Management and the Institute for Policy Analysis. The Faculty also participates in collaborative M.Sc. programs in environmental studies with the Institute for Environmenta Studies. In collaboration with the Faculty of Arts and Science, students may take specialist programs in forest conservation leading to either an Hon.B.Sc. or an Hon.B.A. degree. The B.Sc. (Forest Conservation Science) focuses primarily on forest ecology, biodiversity and conservation biology while the B.A. (Forest Conservation) focuses on communal forest management, forest policy development and related aspects of trade and forest certification.

The Faculty welcomes students from diverse backgrounds particularly forestry, ecology, environmental sciences, international development studies, biology, botany, geography, zoology, agriculture, engineering, mathematics and computer science and social sciences. The Faculty has well-equipped laboratories and computer facilities. The Faculty has a research collaborative agreement with Haliburton Forest and Wild Life Reserve Limited, with a 25,000 ha forest close to Algonquin Park, and also participates in the 400 ha Joker's Hill environmental research forest on the Oak Ridges Moraine.

Direct enquiries to: Faculty of Forestry, University of Toronto, 33 Willcocks St. Toronto, Ontario M5S 3B3; (Phone) 416-978-6152; (Fax) 416-978-3834; (Email) gradprog@forestry.utoronto.ca (WWW) http:www.forestry.utoronto.ca

University The Faculty of Agriculture, Forestry, and Home of Bachelor of Science programs. The four-year Alberta degrees include a BSc in Forestry, Forest Business Management, and Environmental and Conservation Sciences. We also offer a five-year BSc in Environmental and Conservation Sciences/BA in Native Studies Combined degree. The Forestry and Forest Business Management degrees meet Canadian Forestry Accreditation Board standards for professional forestry registration. The Forest Business Management program is offered jointly by AFHE and the School of Business and includes significant offerings in both disciplines. All Forestry and Environmental programs include field schools. Students can choose to participate in an internship program (all degrees) or a coop placement (Business Management). Graduate studies are available, at both the Masters and Doctoral levels. The Faculty prides itself on being a leader in the education and training of resource management from a holistic and integrated perspective. For more information call Student Services at (780) 492-4933 or 1-800-804-6417 (Western Canada) or visit the website at www.afhe.ualberta.ca.



La Faculté de foresterie (FdeF) de l'Université de Moncton, Campus d'Edmundston, offre un programme de baccalauréat et de maîtrise en sciences forestières, ainsi qu'un nouveau programme de baccalauréat appliqué en agroforesterie qui accueillera sa première cohorte étudiante en septembre 2004. Le programme de baccalauréat en sciences forestières de cinq ans permet aux étudiants et étudiantes d'acquérir des connaissances sur les aspects environnementaux, biologiques, socioéconomiques et technologiques reliés à la foresterie. II vise aussi à leur inculquer une vision de l'aménagement intégré des ressources. Il est également offert en régime coopératif, agréé nationalement. Les diplômés et diplômées sont admissibles aux différentes associations professionnelles canadiennes. La maîtrise ès sciences forestières conduit à la réalisation de projets de thèse qui traitent de problématiques diverses : écologie, dynamique et aménagement des écosystèmes forestiers, sylviculture, habitat faunique, géomatique environnementale, foresterie sociale, économique, aménagement des bassins versants, agroforesterie et écophysiologie. La FdeF gère une Forêt expérimentale de 830 ha située à $40 \mathrm{~km}$ d'Edmundston, utilisée pour les travaux pratiques des classes, la recherche et les activités récréatives et éducationnelles. Pour plus de renseignements : Faculté de foresterie, 165, boul. Hébert, Edmundston, N.-B., E3V 2S8. Tél.: 1-800-561-9064 ou (506) 737-5068. Téléc.: (506) 737-5373. Courriel : clajoie@umce.ca Site : www.umce.ca/foresterie

\section{Lakehead}

The Faculty of Forestry and the Forest Environment offers: Honours Bachelor of Science in Forestry (H.B.Sc.F.), Honours Bachelor of Environmental Studies (Forest Conservation) (H.B.E.S.), Bachelor of Environmental Studies (Forest Conservation) (B.E.S.), Master of Science in Forestry (M.Sc.F.) and Master of Forestry (M.F.). The H.B.Sc.F. provides the academic requirements for membership in Canada's Professional Forester Associations. The variety of professional, science and elective courses completed over four years prepares graduates for a wide range of resource management positions. This program is available as a five-year Cooperative Education Option. The HBES/BES curricula combine a core of forestry courses with a broad range of science and arts electives. In this way, the student develops specialization in a complementary area while becoming fully cognizant of forest resource management techniques and challenges. Diploma graduates from forestry and allied disciplines are encouraged to consider application to any of our undergraduate programs. Advanced standing requirements are published in the university calendar and evaluations are completed upon receipt of an application. The M.Sc.F. program is research oriented and requires a thesis. The M.F. emphasizes professional studies and, in particular, advanced skills in forest decision making. Students with undergraduate degrees in allied disciplines are encouraged to apply. Further information may be obtained from: Faculty of Forestry and the Forest Environment, Lakehead University, 955 Oliver Road, Thunder Bay, ON, P7B 5E1, by email: sandy.dunning@lakeheadu.ca or by visiting our website: www.lakeheadforestry.ca.

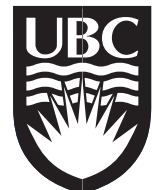

The University of British Columbia, Faculty of Forestry offers four-year degree programs in Forest Resources Management, Forest Operations, Forest Science, Wood Products Processing, and Natural Resources Conservation. The Management and the Operations programs are fully accredited by the Canadian Forestry Accreditation Board. Graduates of these two programs are eligible for registration as Foresters-in-Training in The Association of BC Professionals. Each degree program has required courses designed to enhance knowledge as well as increase technical skills. The Faculty also offers programs leading to MSc, MASc, MF, and PhD degrees in most fields of Forestry and Wood Science. The UBC campus is surrounded by a large forested regional park which is frequently used as an outdoor classroom for forestry labs, in addition the Faculty of Forestry maintains three research forests: the Malcolm Knapp Research Forest in Maple Ridge, the Alex Fraser Research Forest near Williams Lake and the Aleza Lake Research Forest near Prince George. The Faculty of Forestry supports two specialized centres: the Centre for Applied Conservation Research and the Centre for Advanced Wood Processing. Direct enquiries to the Faculty of Forestry, Forest Sciences Centre, 2005-2424 Main Mall, Vancouver, BC, V6T 1Z4, Telephone 604-822-2727, Fax 604-8228645, E-mail forrecep@interchange.ubc.ca Additional information is available at $h t t p: / / w w w . f o r e s t r y . u b c . c a$

For information, please write directly to the school in question. Pour tout renseignement, vous êtes priés d'écrire directement à l'école en question. 


\section{FORESTRY EDUCATION/ÉDUCATION FORESTIÈRE}

\section{UNBC}

The University of Northern British Columbia, Prince George, British Columbia. The College of Science and Management offers BSc programs in Natural Resources Management with a major in Forestry. Other majors in Wildlife and Fisheries, and Resource Recreation are available. MSc and PhD degree programs in Natural Resources and Environmental Studies are also offered. The undergraduate Forestry major is accredited by the Canadian Forestry Accreditation Board. The 4-year program of study includes a number of courses in common with other NRM majors in such areas as forest biology, integrated resource management, resource planning, and professional ethics. The intent is to provide a broad interdisciplinary foundation for specialization in the chosen major. Cooperative education opportunities are also available. UNBC's Prince George campus is strategically located in the centre of the province, amidst the province's major forest resource base, and thus has access to a wide range of forest types. The university has two research forests and an aquatic sciences field station. The wise and sustainable use of our forest, fisheries, recreational and wildlife resources is a potent driver of our educational mission. Faculty members are actively engaged in disciplinary and interdisciplinary research on issues that affect northern British Columbia and similar regions elsewhere in the world. Please direct enquiries to Dr. Keith Egger, Chair of the Ecosystem Science and Management Program, 3333 University Way, Prince George, BC, V2N $4 Z 9$.



La Faculté de foresterie et de géomatique de l'Université Laval est le seul établissement d'enseignement universitair québécois à dispenser des programmes de formation au baccalauréat, à la maîtrise et au doctorat dans les domaines reliés à la gestion de l'environnement forestier, aux opérations forestières, à la transformation des produits de la forêt, de même qu'à l'amélioration de nos connaissances du territoire et de ses ressources. Fière d'une tradition d'excellence construite et entretenue depuis plusieurs années, la Faculté de foresterie et de géomatique offre à ses étudiantes et étudiants des programmes de formation uniques. Académiquement bien structurés, les divers programmes de baccalauréat comportent plusierurs semains de cours de formation pratique de même qu'un programme de stage en milieux de travail, existant tantôt sous le régime coopératif (alternance travail études), tantôt sous la forme d'emplois d'été axés sur la carrière et crédités. Positionnée de façon stratégique en recherche, la Faculté dispose, en plus du Centre de recherche en biologie forestière et du cantre de recherche en géomatique, de plusieurs groupes et équipes structurées qui contribuent à l'avancement des connaissances dans les différents domaines de la foresterie et de la géomatique.

Pour plus de renseignements, veuillez communiquer avec la direction des programmes de premier cycle, Faculté de foresterie et de géomatique, Pavillon AbitibiPrice, Université Laval, Sainte-Foy, Québec G1K 7P4 Téléphone : (418) 6563880; Télécopieur : (418) 656-3177; Courrier électronique : etudes.bacc@ffg.ulaval.ca; Internet : www.ffg.ulaval.ca.

\section{DIPLOMA, CERTIFICATE AND OTHER PROGRAMS / DIPLÔME, CERTIFCAT ET AUTRES PROGRAMMES}

(C)
COLLEE
OFTHE
NORTH
ATLANTIC

College of The North Atlantic, Corner Brook Campus, P.O. Box 822, Corner Brook, NL A2H 6H6.

The College of the North Atlantic offers a group of programs in the natural resources technology field. The two-year Forest Resources Technician diploma program shares many courses with the Fish and Wildlife Technician program. Students can now complete both diploma programs in three years. The Forest Resources program includes a balance of class, lab, and crew fieldwork experiences in forest utilization, protection, improvement, and management. Students are exposed throughout the program to the use of computer technology in general and to GIS software in particular. A wide range of specific technical topics is included with the trend towards integrated management of our natura resources. The Forest Resources program is internationally recognized by the Society of American Foresters, and nationally accredited by the Canadian Council of Technicians and Technologists. For more information, call (709) 637 8517; fax (709) 637-8645; or write to Forest Resources Technician program, Corner Brook Campus, College of the North Atlantic, P. O. Box 822, NL A2H $6 \mathrm{H} 6$

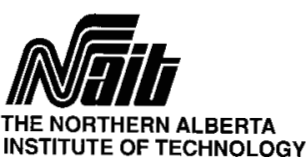

Northern Alberta Institute of Technology offers a two-year diploma in Forest Technology. The program emphasizes training in establishing, tending, protecting and harvesting forest crops. The first year of the program begins with a sixweek field camp, with the balance of the program taught at the main campus in Edmonton. There is a balance between classroom/laboratory and fieldwork in both the first and second years of study. Applicants require the equivalent of an Alberta General High School Diploma or equivalent including English 30 or 33, one of Mathematics 30 or 33 or Math 30 Applied/Math 30 Pure, plus two of Biology 20, Chemistry 20 or Physics 20 , with preference given to applicants with 30-level sciences, St. John Ambulance Standard First Aid Certificate and CPR heart saver. For further information contact the NAIT Registrar's Office at www.nait.ab.ca

For information, please write directly to the school in question.

Pour tout renseignement, vous êtes priés d'écrire directement à l'école en question. 